\title{
Konspirasi Bencana Membongkar Komunikasi Tanda dan Rekayasa Bencana
}

\author{
Fajar Dwi Putra ${ }^{2}$ \\ Universitas Ahmad Dahlan \\ Email: dwiputra@fsbk.uad.ac.id \\ *corresponding author
}

\author{
Keywords: \\ Conspiracy, Sign Communication, \\ Disaster Communication.
}

\begin{abstract}
Disasters that occur in various regions of Indonesia are the result of human imaginations, such as Floods, Erupting Mountains, Landslides and Earthquakes and several other civilizations such as robbery, prostitution, horizontal conflict. This problem The fragile defense of disaster is an illustration and subversion needed to make this country totally paralyzed by the results of disaster consistency. This analysis of research emphasizes more on how to analyze disasters that are the result of conspiracy communication of a number of stakeholders to undermine the system and strength of a country through a sign and symbol.

As we all know that Indonesia is a ring of fire or fire ring country surrounded by Volcanoes so the potential due to Mount eruption is still high. Not only volcanoes, Indonesia also stands on a fault that can shift at any time and cause a big shock or earthquake. In addition, Indonesia has the texture of lands prone to landslides, flood-prone areas, high potential for rainfall and several other potential disasters. The lack of knowledge about reading signs will be very worrying for the integrity of a community in disaster-prone areas. To examine this study, the author uses qualitative research methods as a power base to describe everything about signs in the results of this study.

From the results of this research, a cause and effect arises that we should be able to understand among humans. Regarding disaster and symbolization in it. This means that many people who cannot read the signs, even if they can read the signs, the habits only save themselves and do not dare to say it out or convey it to others..
\end{abstract}

\begin{abstract}
ABSTRAK
Bencana yang terjadi di berbagai wilayah di Indonesia diduga merupakan hasil rekaan manusia, seperti Banjir, Gunung Meletus, Longsor dan Gempa Bumi serta beberapa bencana sosial lainnya seperti perampokan, prostitusi, konflik horizontal. Sehingga hal ini memicu permasalahan pertahanan negara. Pertahanan yang rapuh tentang kebencanaan merupakan ilfitrasi maupun subversi yang nantinya bisa membuat kesatuan negara tersebut lumpuh total akibat konspirasi kebencanaan.

Penelitian analisis ini lebih menekankan kepada bagaimana menganalisis kebencanaan yang merupakan hasil konspirasi komunikasi sejumlah pemangku kepentingan untuk meruntuhkan sistem dan kekuatan suatu negara melalui sebuah tanda dan simbol.

Seperti yang kita ketahui bersama bahwa Indonesia merupakan ring of fire atau negara cincin api yang dikelilingi oleh Gunung Berapi sehingga potensi akibat erupsi Gunung masih tinggi. Tidak hanya kegunungapian, Indonesia juga berdiri diatas patahan yang sewaktu-waktu bisa bergeser dan mengakibatkan goncangan besar atau gempa bumi. Selain itu juga, Indonesia mempunyai tekstur tanah yang rawan longsor, kawasan rawan banjir, potensi curah hujan yang tinggi dan beberapa potensi bencana yang lainnya.
\end{abstract}


Minimnya pengetahuan tentang membaca tanda akan sangat mengkhawatirkan untuk keutuhan sebuah masyarakat yang berada di kawasan rawan kebencanaan. Untuk menelaah penelitian ini, penulis menggunakan metode penelitian kualitatif sebagai sebuah basis kekuatan mendeskripsikan segala sesuatu tentang tanda dalam hasil penelitian ini.

Dari hasil penelitian ini muncullah satu sebab akibat yang semestinya kita bisa pahami antar sesama manusia. Mengenai bencana dan simbolisasi di dalamnya.

Kata Kunci:

Konspirasi, Komunikasi Tanda, Komunikasi Bencana Artinya banyak masyarakat yang tidak bisa membaca tanda, kalaupun bisa membaca tanda, maka kebiasaaan hanya menyimpan sendiri dan tidak berani mengatakannya keluar atau menyampaikannya kepada orang lain.

Copyright (C) 2019 Channel Jurnal Komunikasi. All right reserved.

\section{PENDAHULUAN}

Jika dipikir secara logika, terjadinya penyakit seperti virus dan flu burung bisa saja ulah manusia, atau paling tidak manusia mengetahui bagaimana pencegahannya tetapi lebih memilih diam dan menyelamatkan keluarganya. Atau yang lebih ekstrem lagi adalah terjadinya gempa bumi bisa dikatakan ulah manusia karena penyuntikan beberapa zat dan cairan kimiawi ke dalam tanah sehingga menyebabkan destruktif ${ }^{1}$ yang luar biasa. Akibatnya adalah kerugian yang meluas dan berdampak buruk kepada manusia serta Alam.

Seperti yang diketahui, konspirasi adalah bentuk persekongkolan sekelompok manusia demi meraup keuntungan pribadi atau dengan kata lain disebut Oportunis ${ }^{2}$ konspirator melakukan hal demikian secara utuh, rapi dan rahasia sehingga hal sekecil apa pun tidak dapat diketahui secara luas. Hal ini dilakukan untuk memberikan efek teror dan tidak nyaman. Yang menjadi sasaran bisa bentuk pemerintahan, pertahanan sipil negara atau organisasi masyarakat tertentu.

Setelah berbagai peristiwa tsunami di Aceh dan angin topan Atlantik 2005. Banyak warga yang mempertanyakan se "alami" apakah bencana Alam terjadi, dan se "natural" apakah sistem kebencanaan itu disusun sedemikian rupa sehingga muncul beberapa kerugian besar di masyarakat. Mungkin kita perlu berpikir sedikit lebih jauh, untuk "mengubah" iklim, menciptakan gempa bumi dan ledakan gunung berapi dari jarak jauh melalui gelombang elektromagnetik?

Apakah memang benar "pengendalian" cuaca merupakan unsur atau sinyalemen terjadinya sebuah konspirasi besar di baliknya?

\section{KAJIAN TEORI}

Salah satu kajian yang akan penulis kemukakan adalah bagaimana sebuah tanda itu bisa dilihat, dirasakan dan akhirnya diterjemahkan. Intinya penerjemahan tanda ini memerlukan bentuk komunikasi intrapersonal dan juga kelompok. Penulis merujuk kepada pendapat Suassure dalam Berger yang mengatakan bahwa tanda disusun oleh dua elemen. Yang pertama adalah aspek citra dan bunyi (semacam kata atau representasi visual) dan suatu konsep tempat citra, bunyi itu disandarkan. (Berger:2015;13)

Jika diterjemahkan secara deskriptif, pendapat itu bermakna semua yang akan terjadi harus mempunyai unsur dapat dilihat, dapat diperkirakan dan harus dipelajari segala dampak dan hasilnya.

Jika dilihat secara dasar pengetahuan, pemahaman tentang bencana adalah kejadian yang membawa dampak kerugian besar. Artinya apa, semua hal yang sifatnya KLB atau kejadian luar biasa, bisa dikategorikan sebagai sebuah bencana. Tidak selalu harus berkaitan dengan Alam, perang, permusuhan secara masiv $^{3}$ juga masuk kategori kebencanaan.

Secara pengalaman, penulis pernah mengalami peristiwa bencana gempa bumi Yogyakarta pada tanggal 27 Mei 2006. malam sebelum kejadian, terdengar suara seperti batu dilempar ke dalam air. Paginya gempa bumi dahsyat menghancurkan Yogyakarta. Korban tewas 4.893 jiwa, kepanikan warga akibat hoax rumor terjadinya gelombang tsunami, gedung dan beberapa infrastruktur rusak parah, bantuan tidak merata, dan beberapa dampak psikologis pasca gempa.

\section{KONSPIRASI}

Secara garis besar, pengetahuan bahwa bencana (dalam hal ini bencana alam) bisa dibuat berdasarkan pesanan suatu kelompok memang ditengarai benar adanya. Mereka dengan sengaja membuat sebuah perencanaan bencana sesuai tarif, pesanan dan keinginan pribadi. Lalu, apa yang bisa dianalisis dari sisi komunikasinya?

Sesuatu dikatakan tujuan jika sudah memilik kerangka berpikir, lalu sudah ada rancangan untuk mengambil, memperoleh serta mendistribusikan tujuan tersebut dengan langkah-langkah tertentu. Konsprirasi adalah bentuk "kolusi"

1 Sifat merusak.

2 Sifat ingin untung sendiri.

3 Meluas. 
untuk mengelabuhi sebuah pemerintah atau dengan kata lain untuk mengkudeta sebuah pemerintahan. Bisa juga dikaitkan dengan penebaran teror dengan cara menciptakan fitnah.

\section{METODE PENELITAN}

Pada dasarnya, penelitian ini dilakukan dengan metode analisis deskriptifkualitatif. Penulis menggunakan metode bercerita untuk menggambarkan dan menganalisis komunikasi tanda untuk tujuan kebencanaa diantaranya adalah. (1) Wawancara, Wawancara adalah bentuk komunikasi verbal yang bertujuan untuk memperoleh informasi yang jelas dan diinginkan. Dalam penelitian ini penulis melakukan wawancara dengan pelaku dan korban bencana. (2) analisis data tentang teori semiotika kebencanaan.

Dengan dua dasar diatas, penulis yakin akan dapat merumuskan data, tanda, sinyalemen dan ekpresi akan terjadinya sebuah bencana. Sehingga dengan penelitian ini akan didapat sebuah metode khusus untuk menangkal bencana atau minimal mengurangi jumlah korban.

\section{TEMUAN DATA PENELITIAN}

Bencana yang sudah terjadi dan yang akan terjadi sebenarnya adalah karena ulah manusia. Bisa disebut sebagai sebuah "karmatologi" atau sistem sebab akibat (kausalitas) antara manusia dengan manusia, manusia dengan Tuhan dan manusia dengan Alam. Jadi, secara empiris, bencana yang terjadi adalah bentuk rekayasa manusia, entah itu disadari atau tidak disadari. Untuk itu perlu kiranya sebuah metode yang komunikatif guna mempersempit ruang gerak terjadinya bencana.

\section{BENCANA ALAM}

Data yang penulis temukan di lapangan adalah, bahwa unsur bencana Alam sudah mereka sadari namun kesadaran akan hal itu masih minim. Warga sadar bahwa penambangan pasir di Merapi misalnya akan menimbulkan kebencanaan seperti longor, namun warga mengatakan bahwa itu sudah hal biasa. Jadi tidak ada pilihan lagi. Selain kondisi ekonomi yang rendah, kesadaran pendidikan non formal juga masih tipis. Padahal beberapa instansi, komunitas dan juru kunci Merapi sudah memperingatkan bahwa akan berbahaya jika aktivitas penambangan pasir masih dilakukan.

Meletusnya Merapi tahun 2010, juga sudah merupakan sebuah tanda dengan cara peningkatan status Merapi. Tetapi, warga memilih untuk bertahan sebelum Merapi benar-benar meletus. Tanda seperti yang diungkapkan Saussure memang bisa digunakan secara empiris, namun semua itu tergantung dari individunya. Bahwa sudah diadakan sosialisasi tentang vulkanologi Merapi membuat warga tidak peduli. Mereka masih nyaman dengan status Merapi yang kala itu masih siaga.

Tanda-tanda alam seperti turunnya beberapa hewan sudah terbaca dan dapat dibaca oleh warga dengan sangat jelas. Mereka sebenarnya sudah paham akan hal itu, tetapi keteguhan hati mereka masih belum bisa ditawar oleh tanda apa pun.

\section{BENCANA SOSIAL}

Bencana sosial adalah peristiwa atau serangkaian peristiwa yang disebabkan karena ulah manusia diantaranya konflik sosial antar kelompok dan terjadinya aksi teror. Begitu banyak bencana sosial di Indonesia yang menjadi konsumsi publik. Peperangan sosial antar ras, suku dan agama, konflik horizontal sesama saudara yang justru berimplikasi terhadap stabilitas kenegaraan dan status sosial di masyarakat.

Beda selisih akan mengakibatkan kesalahpahaman yang berujung peperangan, tawuran dan hujat menghujat. Data yang penulis temukan meliputi adanya tingkat emosional yang tidak stabil, adanya ketidakpahaman tentang suatu hal, adanya ketidakselarasan tentang berbagai kondisi sosial di masyarakat, dan rendahnya pendidikan karakter di Indonesia.

Pada intinya baik itu bencana Alam atau bencana sosial ada campur tangan manusia dan itu melibatkan beberapa tanda, simbol, penanda dan pertanda. Rendahnya pemahaman tentang simbol, tanda, penanda dan pertanda akan berakibat munculnya bencana.

\section{HASIL DAN PEMBAHASAN}

\section{A. Tanda Imajiner Bencana Alam}

Apa yang dimaksud dengan tanda imajiner? Tanda imajiner adalah tanda yang tidak terdapat dalam dunia nyata seperti pikiran, keinginan dan harapan. Seperti yang terjadi di kawasan penambangan pasir Merapi. Para pengelola pada awalnya mempunyai keinginan untuk menciptakan kehidupan yang layak dengan cara menambang pasir. Sebab pasir yang ditambang bisa dijual dan mempunyai harga yang tinggi. Dari keinginan itu, mereka sadar bahwa aktivitas penambangan pasir akan merusak Alam dan menimbulkan bahaya parsial, tetapi karena harapan, keinginan yang juga tinggi maka mereka cenderung mengabaikannya. 
Penulis berpendapat, sistem manajerial di dalam individu merupakan hal penting untuk dijadikan rujukan dalam mengelola sistem sosial dan kebencanaan. Masyarakat akan terpecah menjadi beberapa golongan karena sistem atau tingkat pemahaman mengenai tanda sangatlah minim. Kesadaran akan dampak, korban dan kehancuran masih jauh dari kata sempurna. Sehingga menjadikan masyarakat menciptakan bencana secara tidak sadar. Bahkan di beberapa wilayah terdapat bencana psikologi yang akibat dari itu muncullah beberapa kelompok-kelompok yang melakukan patologi sosial seperti $k_{l i t i h}{ }^{4}$ dan beberapa fenomena sosial lainnya.

Tidak hanya sosial, bencana Alam juga dapat dijadikan pelajaran, karena tanda-tanda itu sudah mulai muncul dan bahkan dimunculkan secara sengaja. Para pemangku kepentingan (kapitalis) tahu (bahkan memanfaatkan) kekurangan masyarakat Indonesia. Mereka sadar budaya di Indonesia yang cenderung bergantung kepada sesuatu masih sangat tinggi. Relevansinya jelas akan berdampak kepada sifat destruktif individu dan sosial.

Alam memang tidak bisa diprediksi. Salah satu, bahkan satu-satunya bencana Alam yang tidak dapat diprediksi adalah terjadinya gempa bumi. Meski begitu, tanda, penanda, pertanda dan simbol dapat dipelajari secara pengetahuan sains. Misalnya Indonesia berada di antara lempengan Indo Australia, Urasia dan Pasifik. Sehingga ketiga lempengan itu akan memunculkan lempengan baru yang disebut dengan Translasional dan Kompresional. Translasional adalah lempengan yang selalu bergerak, sedangkan Kompresional adalah lempengan yang terjadi akibat tekanan atmosfir dan fakor lingkungan. Ini adalah sebuah pengetahuan yang bisa dijadikan tanda, penanda, pertanda dan simbol. Tetapi masyarakat Indonesia lebih mementingkan sifat malas untuk mempelajari sesuatu.

Jika hal itu dipelajari, maka akan muncul kesadaran, meski dalam hal bencana gempa tidak bisa mutlak diberlakukan. Tetapi ada sebuah usaha pemahaman yang berujung kepada gejala preventif $f^{5}$ seperti penguatan bangunan rumah dan beberapa infrastruktur lainnya.

Terdapat lima tahapan untuk mengetahui bencana Alam. Kelima tahapan itu sebenarnya bisa dijadikan sebuah tanda. (1) injeksi ${ }^{6}$ cairan yang terlalu besar ke bumi. (2) Ekskavasi ${ }^{7}$ cairan ke bumi dengan cara pengecoran ke dalam tanah dalam skala besar. (3) uji coba nuklir. (4) Esktraksi ${ }^{8}$ cairan ke bumi dan (5) adalah pembangunan waduk.

Injeksi cairan ke bumi adalah bentuk rekayasa manusia untuk memunculkan getaran yang maha dahsyat ke dalam tekstur tanah. Sehingga jika cairan itu dimasukkan ke tanah, maka akan terjadi reaksi dan muncullah getaran yang akan menimbulkan bencana gempa.

Ekskavasi cairan ke tanah, proses pengecoran yang berlebihan akan menimbulkan getaran dan kekurangan pondasi yang kuat. Logikanya jika tanah terus menerus digali, maka akan keropos, dan ketika pertahanan tanah itu sudah tidak kuat lagi, maka akan rentan terjadinya bencana tanah longsor.

Uji coba nuklir di Indonesia memang jarang dilakukan. Tetapi jangan lupa bahwa Indonesia punya reaktor nuklir yang sewaktu-waktu bisa bocor karena ulah atau kecerobohan manusia. Di Jogja misalnya, ada BATAN (Badan Tenaga Nuklir Nasional) yang dalam waktu tidak menentu bisa saja meledak dan meracuni masyarakat. Itu pun sebuah tanda kebencanaan yang harus diperhatikan dengan saksama.

Ekstraksi cairan ke bumi. Hal ini terjadi jika masyarakat tidak cermat dalam melakukan pembuangan sampah, pemisahan zat-zat yang terdapat dalam makanan dan minuman. Jika ini dibiarkan maka akan meracuni tanah, terjadilah pencemaran lingkungan dan pada akhirnya menimbilkan wabah penyakit. Penulis mengindikasikan justru hal ini dijadikan sebuah "bisnis" oleh beberapa kaum kapitalis atau mungkin juga memang karena tingkat kesadaran manusia yang masih rendah.

Penambangan waduk. Kenapa ini dimasukkan kedalam tahapan terjadinya bencana? Sebab jika pengerukan waduk atau pembuatan waduk memakan tanah yang terlalu dalam dan luas maka akan terjadi abrasi $^{9}$ dan jika turun hujan dengan kapasitas tinggi dikhawatirkan akan terjadi longsor dan dapat menimbulkan korban jiwa.

Penulis mencoba mewawancarai MN pelaku penambangan pasir ilegal di kawasan lereng Merapi. Identitas pelaku penulis samarkan karena berkaitan dengan etika penelitian. Dari data wawancara yang di dapat, penulis menemukan unsur kesengajaan dari pelaku.

"Sudah tahu saya Mas kalau ini akan menimbulkan bencana. Tapi gimana lagi, keluarga, anak-anak saya harus tetap sekolah. Kalau saya tidak nambang pasir, mereka makan apa? Lagian pemerintah juga aman-aman saja, kami tidak ditindak tegas, meskipun beberapa waktu lalu ada himbauan untuk berhenti menambang, tapi saya tetap saja nambang",

4 Aksi kejahatan yang dilakukan oleh anak muda bermotor.

5 Pencegahan.

6 Penyuntikan.

7 Penggalian.

8 Pemisahan suatu zat berdasarkan perbedaan kelarutannya.

9 Pengikisan. 
Hal serupa juga dikatakan oleh PM seorang penambang pasir di kawasan utara lereng Merapi. PM mengetahui secara pasti, bahkan dia sadar keluarganya pun terancam bencana longsor. Tapi PM tidak bisa berbuat apa-apa.

"Wadu kalau sudah bicara soal perut saya enggak bisa komentar banyak Mas. Cari kerjaan sekarang susah, kemampuan saya juga cuma bisa ini saja. Ya kalau dibilang takut ya takut Mas. Bahkan keluarga saya jadi taruhannya, mereka sewaktu-waktu bisa terkena longosr akibat ulah saya. Kadang saya mikir sampai sana juga, tapi ya mau gimana lagi Mas”

Kesimpulannya adalah kesadaran individu tentang tanda dan dampak aktivitas masih minim. Warga mengetahui tanda, bisa membaca tetapi itu tidak diindahkan dan hanya dijadikan wacana sekilas saja.

\section{BENCANA SOSIAL}

\section{A. Patologi Sosial}

Jika kita ambil secara mendasar, pemahaman Patologi sosial adalah ilmu tentang penyakit. Yang dimaksud dengan penyakit ini adalah penyakit masyarakat seperti kenakalan remaja, prostitusi (online), tawuran, konflik horizontal dan beberapa penyakit masyarakat lainnya.

Dari teori diatas, penulis mengkaitkan dengan apa yang terjadi di Indonesia belakangan ini. Terjadinya konflik sosial, prostitusi online dimana-mana, perampokan, kejahatan dan beberapa kondisi sosial lainnya.

Dari pandangan ini menyebutkan bahwa masyarakat selalu dalam keadaan sakit atau masyarakat yang tidak berfungsi secara sebagian atau keseluruhan. Masyarakat dikatakan sehat jika elemen-elementnya berfungsi secara sempurna dengan tanda tidak adanya ketimpangan sosial, tidak adanya konflik besar yang merugikan masyarakat luas.

Mengapa masyarakat menjadi sakit? Konsep dasarnya bermula dari masyarakat modern yang serba kompleks sebagai hasil produk dari kemajuan teknologi. Mekanisasi, industrilisasi dan urbanisasi yang kesemuanya memunculkan banyak permasalahan sosial sehingga adaptasi terhadap masyarakat modern menjadi tidak mudah.

\section{B. Faktor Penyebab Terjadinya Patologi Sosial}

Kemiskinan. Munculnya kemiskinan sangat dipengaruhi oleh kebutuhan dasar atau sulitnya akses pendidikan dan pekerjaan. Seperti yang kita ketahui, kemiskinan merupakan masalah global yang menggerogoti sistem pertahanan psikologis manusia.

Selain faktor kemiskinan, ada juga faktor ekonomi yang berdampak kepada krisis mental dan moral. Faktor inilah yang menjadi dasar utama terjadinya perampokan, kejahatan kerah putih ${ }^{10}$ dan berbagai anomali lainnya di masyarakat yang jika dibiarkan akan menimbulkan dampak bencana sosial besar.

Faktor budaya. Tidak dapat dipungkiri bahwa Indonesia sebagai negara yang multibudaya dan budaya menjadi identitas suatu daerah. Pada satu sisi multibudaya dapat dijadikan sebagai salah satu unsur perekat sosial. Namun di sisi lain, budaya juga berpotensi untuk menimbulkan gesekan sosial. Hal ini yang sedang terjadi di Indonesia, gesekan antar budaya yang mengatasnamakan dirinya sebagai masyarakat berbudaya justru menjadi ladang peperangan suku, ras dan agama. Dampaknya jelas bahwa itu merugikan masyarakat luas.

Seperti apa dan bagaimana cara kerja tanda bencana sosial bisa dilihat dari ketidakpahaman tentang suatu hal. Dibesar-besarkan lalu dijadikan komoditi umum dan pada akhirnya kesalahpahaman yang terjadi.

Fenomena inilah yang disebut dengan bencana sosial. Dari data yang penulis temukan, degradasi ${ }^{11}$ moral masih mendominasi beberapa kalangan masyarakat. Itu terkait dengan budaya Indonesia yang lebih menggantungkan dan berpikir belum visioner. Pandangan seperti ini (visioner, pandangan jauh ke depan) merupakan konsep tanda imajiner yang harus dimiliki oleh setiap individu. Sehingga akan tercipta keselarasan yang tinggi dan kekompakan yang ideal.

Dibutuhkan sebuah komunikasi pemahaman tentang tanda imajiner seperti ini. Merujuk kepada masih banyaknya kesalahpahaman yang berakibat bencana sosial.

Penulis melakukan wawancara eksklusif dengan korban dan pelaku Patologi sosial. Narasumber pertama adalah YY korban aksi klitih yang terjadi di Bantul Yogyakarta beberapa bulan yang lalu.

"Ngeri Mas kalau tahu itu, saya jadi takut untuk keluar malam. Hmm kalau dibilang sebabnya ya mungkin karena kurangnya pendidikan, krisis ekonomi yang sekarang apa-apa mahal. Tapi kok saya lebih ke kemerosotan moral bangsa, khususnya anak muda dalam beretika di jalan. Lha gimana, saya enggak salah apa-apa kok di bacok kan edan Mas kwi. Saya merasa tidak punya musuh sama sekali. Katanya sih karena saya menghalangi jalan. Lha itu kan jalan umum, saya juga bayar pajak, lalu dimana salah saya? Ya tadi itu sih Mas, kemerosotan moral"

10 Korupsi.

11 Kemerosotan. 
Data dari korban, penulis konfirmasi ke palaku klitih yang sudah tertangkap.

"Ya wis, saya juga ikut-ikutan Mas, saya sebenarnya memang enggak kenal sama korban. Tapi, karena pengaruh teman ya gini hasilnya. Sekolah saya hancur, keluarga saya juga pasti kecewa. Intinya saya dan teman-teman saya memang tidak mempunyai motif apa-apa kecuali ingin dianggap di masyarakat”"

\section{KESIMPULAN}

Bencana Alam dan sosial merupakan “kesepakatan” bersama antara manusia dengan manusia yang dikomunikasikan dengan simbol. Mereka cenderung memberlakukan sistem ketidakpahaman untuk membuat sebuah konvensi ${ }^{12}$ bersama.

Masyarakat harus cerdas membaca bentuk komunikasi tanda, baik itu tanda pararel atau tanda imajiner. Sehingga ke depannya akan tercipta keberlangsungan hidup yang baik, tidak ada lagi korban jiwa berjatuhan meskipun misal ada korban jiwa setidaknya mengurangi jumlahnya.

Masyarakat harus merujuk kepada pengetahuan simbol, pemahaman tanda dan penerjemahan arti dibalik semua tanda. Masyarakat juga harus berani untuk mengkomunikasikan (mensosialisasikan) tanda itu kepada masyarakat melalui media apa saja termasuk media sosial.

\section{DAFTAR PUSTAKA}

Habermas, J. (2007). Kritik atas Rasio Fungsionalis. Yogyakarta: Kreasi Wacana.

Jamaludin, D. A. (2016). Dasar-Dasar Patologi Sosial. Bandung: CV Pustaka Setia .

Moron Deutsch, P. T. (2016). Handbooks Resolusi Konflik. Bandung: Nusa Media.

Smith, J. E. (2013). Konspirasi Bencana Alam. Jakarta Selatan: PT Ufuk Publlishing House.

Wahyuni, I. N. (2014). Komunikasi Massa. Yogyakarta: Graha Ilmu . 